\title{
Inovasi dan Implementasi Pembelajaran Sejarah di Era Merdeka Belajar
}

\section{Prof. Dr. Nana Supriatna, M.Ed}

Guru Besar Pendidikan Sejarah UPI nanasup@upi.edu

\section{INOVASI DAN IMPLEMENTASI PEMBELAJARAN SEJARAH DI ERA MERDEKA BELAJAR} Webinar Prodi S2 Pendidikan Sejarah Universitas Sebelas Maret SABTU, 29 AGUSTUS 2020

Prof. Dr. Nana Supriatna, M.Ed.


Social, Humanities, and Education Studies (SHEs): Conference Series https://jurnal.uns.ac.id/shes 

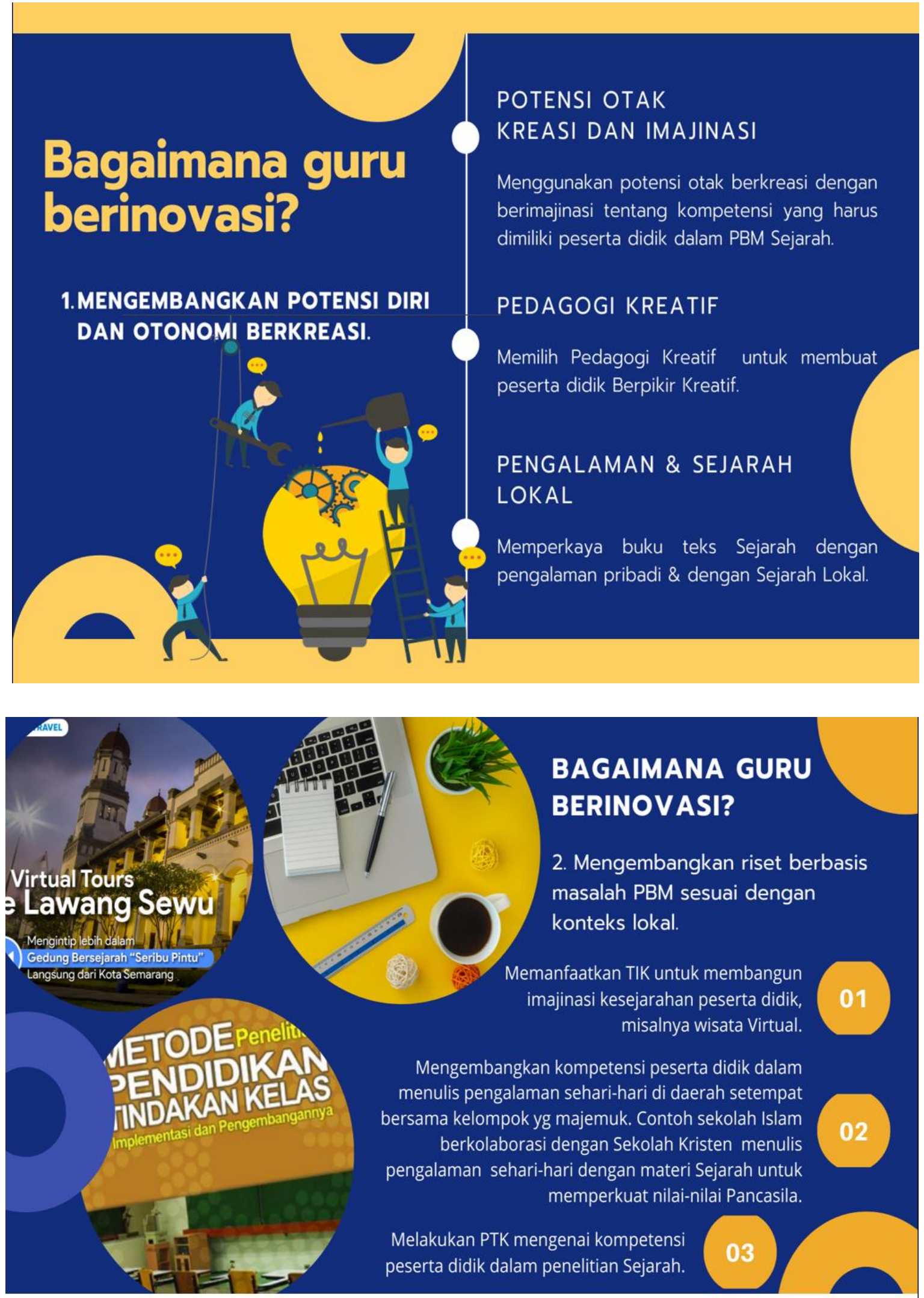


\section{BAGAIMANA GURU BERINOVASI?}

3. Mengembangkan potensi belajar peserta didik sebagai pelaku Sejarah pada zamannya.

Menghubungkan semua materi sejarah dg pengalaman dan kondisi peserta didik. Contoh, peristiwa Sumpah Pemuda dengan peran peserta didik sebagai pemuda kekinian.
Mengaplikasikan berpikir kesejarahan dalam tindakan nyata. Misalnya, konsep pahlawan menjadi jiwa kepahlawanan masa kini.


\section{.}
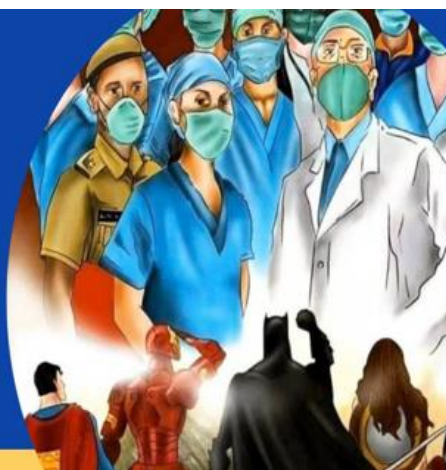